\title{
BAX regulates follicular endowment in mice
}

\author{
Chuck R Greenfeld, Melissa E Pepling ${ }^{1}$, Janice K Babus ${ }^{2}$, Priscilla A Furth ${ }^{3}$ and Jodi A Flaws ${ }^{2,4}$ \\ Department of Physiology, University of Maryland, Baltimore, Maryland 21201, USA, ${ }^{1}$ Department of Biology, \\ Syracuse University, Syracuse, New York, 13244, USA, ${ }^{2}$ Department of Epidemiology and Preventive Medicine, \\ University of Maryland, Baltimore, Maryland 21201, USA, ${ }^{3}$ Department of Oncology, Lombardi Cancer Center, \\ Georgetown University, Washington, District of Columbia 20057, USA and ${ }^{4}$ Department of Veterinary Biosciences, \\ University of Illinois, Urbana, Illinois 61802, USA
}

Correspondence should be addressed to J A Flaws; Email: jflaws@uiuc.edu

\begin{abstract}
It is believed that the endowment of primordial follicles in mammalian ovaries is finite. Once follicles are depleted, infertility ensues. Thus, the size of the initial endowment has consequences for fertility and reproductive longevity. Follicular endowment is comprised of various processes that culminate with the incorporation of meiosis-arrested oocytes into primordial follicles.

Apoptosis is prominent during follicular endowment, and apoptosis regulatory genes are involved in its regulation. Conflicting data exist with regard to the role of the proapoptotic Bcl-2 associated X protein (BAX) in follicular endowment. Therefore, we investigated the role of BAX during follicular endowment in embryonic and neonatal ovaries. We found that BAX is involved in regulating follicular endowment in mice. Deletion of Bax yields increased oocyte numbers in embryonic ovaries and increased follicle numbers in neonatal ovaries when compared with wild-type ovaries. Increased follicular endowment in Bax $-/-$ ovaries is not due to enhanced germ cell viability. Further, it is not due to an increased primordial germ cell (PGC) allotment, a delay in the onset of meiosis, or altered proliferative activity of oogonia. Instead, our data suggest that the regulatory activity of BAX in follicular endowment likely occurs during PGC migration, prior to PGC colonization of the gonad.

Reproduction (2007) 133 865-876
\end{abstract}

\section{Introduction}

Female mammals are endowed with a large complement of primordial follicles within their ovaries at birth or shortly thereafter. Primordial follicles are small dormant structures consisting of an immature oocyte surrounded by a layer of flattened granulosa cells. Throughout the reproductive lifespan of the female, cohorts of these follicles are continuously selected to initiate growth and mature to ovulation. It has long been believed that the primordial follicle population is finite (Zuckerman 1951), and thus once the follicles have been depleted by growth initiation and death, infertility ensues. This long-held notion was recently challenged by the work suggesting that postnatal (PN) oogenesis, and thus the formation of new follicles, occurs in mice (Johnson et al. $2004,2005)$. These reports have been met with skepticism (Greenfeld \& Flaws 2004, Telfer et al. 2005) and thus, it is still predominately accepted that oogenesis is restricted to embryonic life and that the primordial follicle population is finite.

The primordial follicle population is formed during embryonic and neonatal life by a series of processes collectively referred to as follicular endowment (reviewed in Hirshfield 1991). Follicular endowment begins with the allocation of a founder population of primordial germ cells (PGCs), which are the embryonic precursors of adult gametes, the male spermatozoa, and female oocyte (reviewed in Starz-Gaiano \& Lehmann 2001). PGCs are allocated from precursor cells in the proximal epiblast during gastrulation, with the first PGCs identifiable around embryonic day (E)7.2 in mice, at the base of the allantois (reviewed in Ginsburg et al. 1990, Lawson \& Hage 1994, Tam \& Zhou 1996, De Felici et al. 2004).

The founder population of PGC numbers is only about 45 in mice (Lawson \& Hage 1994), and migrates through the hindgut to colonize the developing gonad by E11.5 (reviewed in Molyneaux \& Wylie 2004). During migration, and after colonization of the gonads, PGCs are proliferative, dividing every $16 \mathrm{~h}$ (Tam \& Snow 1981, Lawson \& Hage 1994) until E13.5, at which point they enter mitotic arrest in males, or meiosis in females (McLaren 1988). The proliferative activity of germ cells expands the germ cell population to 25000 at E13.5 (Tam \& Snow 1981). Coincident with meiotic entrance, germ cell attrition, the apoptotic death of oocytes, begins (reviewed in Reynaud \& 
Driancourt 2000). Germ cell death is first observed around E13.5-15.5 in the mouse (Coucouvanis et al. 1993, Ratts et al. 1995). Attrition leads to a continuous loss of oocytes throughout fetal development and into early neonatal life, resulting in a loss of $65 \%$ of germ cells between E13.5 and birth in mice (McClellan et al. 2003).

Once PGCs have colonized the gonad midway through gestation, they assume a nonmotile morphology and very closely associate with one another in discrete clusters that resemble Drosophila germ cell cysts or nests (GCN; Gomperts et al. 1994, Pepling \& Spradling 1998, Molyneaux et al. 2004). GCN are present in mice by E10.5, and are comprised of a group of interconnected, synchronously dividing germ cells, and surrounded by a layer of somatic cells (Pepling \& Spradling 1998, 2001). GCNs begin to break down shortly after birth to facilitate primordial follicle formation (Pepling \& Spradling 2001). GCN breakdown appears to occur due to oocyte death within the GCN, which serves to break the connections between oocytes and permits somatic cells to envelop surviving oocytes, thus forming primordial follicles (Pepling \& Spradling 2001). In mice, primordial follicle formation is completed by PN day 7 (Pepling \& Spradling 2001).

Germ cell death is a prominent feature of follicular endowment and its proper regulation is essential for the endowment of a sufficient follicle population to sustain the fertility of the female. Studies have demonstrated that mutations in apoptosis regulatory genes lead to the dysregulation of follicular endowment, and the presence of a follicle surfeit or deficiency in neonatal ovaries. For example, deletion of the proapoptotic caspase 2 leads to excess follicles in neonatal ovaries (Bergeron et al. 1998). Similarly, deletion of acid sphingomyelinase (Smpd1), which produces the death-inducing second messenger ceramide through membrane hydrolysis (reviewed in Gulbins 2003), enhances follicular endowment (Morita et al. 2000). Deletion of various members of the B-cell lymphoma/leukemia $(B C l)-2$ family have been shown to produce similar alterations in follicle numbers in neonates. For example, loss of function of the anti-apoptotic protein BCL-XL leads to follicle deficiency in neonatal ovaries due to decreased oocyte survival in embryonic life (Rucker et al. 2000). Similarly, deletion of the anti-apoptotic BCl-2 reduces follicular endowment (Ratts et al. 1995), whereas overexpression of $\mathrm{BCl}-2$ enhances follicular endowment (Flaws et al. 2001), presumably due to alterations in oocyte viability (Flaws et al. 2006).

In contrast to the effect observed on primordial follicle numbers following the deletion of these anti-apoptotic BCL-2 family members, deletion of the proapoptotic BCL-2 family member Bax was not observed to affect follicle numbers in neonatal mice, suggesting that it is not involved in regulating follicular endowment (Perez et al. 1999). A lack of effect of Bax deletion on oocyte survival and follicle numbers is very surprising given the findings of more recent studies. For example, De Felici et al. (1999) showed that BAX is upregulated in ovaries during germ cell attrition and in cultured fetal oocytes undergoing apoptosis. Further, deletion of Bax rescues loss of BCL-XL function, restoring follicle numbers to wild-type (WT) levels (Rucker et al. 2000). It was also shown that BAX is involved in promoting the death of ectopic germ cells that fail to correctly migrate to the gonads (Stallock et al. 2003). These latter studies suggest that BAX is a regulator of germ cell death during follicular endowment. The contradiction between these studies and that of Perez et al. (1999) is puzzling, and could suggest that although BAX appears to be involved in regulating oocyte death during follicular endowment, it is not essential. Alternatively, it could be that BAX is involved in regulating follicular endowment, but the data presented by Perez et al. (1999) do not allow this interpretation. In the study by Perez et al. (1999), follicle numbers at PN4 were compared, and the number of naked oocytes (i.e., those remaining within $\mathrm{GCN}$ that have yet to be incorporated into follicles) were not presented. As follicle formation is not completed before PN7 (Pepling \& Spradling 2001), PN4 is too early a time point to assess the effect of Bax deletion on follicle formation without presenting the total number of oocytes present in the ovaries.

Due to the contradictory data reported in the studies discussed earlier and the equivocal nature of the role of BAX during follicular endowment, we investigated the effect of Bax deletion throughout embryonic and neonatal ovarian development. Specifically, we tested the hypothesis that BAX negatively regulates follicular endowment by promoting oocyte death during germ cell attrition and GCN breakdown.

\section{Materials and Methods}

\section{Animals and treatment}

WT and $\mathrm{Bax}-/-$ mice in a C57BL/6 background were used in all experiments. For experiments involving embryos, timed matings were established and the morning of the observation of a vaginal plug was designated as E0.5. The day of birth was considered to be PNO. Animals were housed in clear plastic cages and maintained on a $12 \mathrm{~h}$ light: $12 \mathrm{~h}$ darkness cycle in a temperature-controlled room $\left(24 \pm 1{ }^{\circ} \mathrm{C}\right)$ with $35 \pm 4 \%$ relative humidity. Mice were provided food and water ad libitum. The University of Maryland Institutional Animal Use and Care Committee approved all protocols involving mice.

\section{Screening/genotyping mice}

Ear-punch tissue collected from pups was lysed in $9 \mu \mathrm{l}$ water containing proteinase $\mathrm{K}(4 \mathrm{mg} / \mathrm{ml}$; Ren et al. 2001). Tissue was digested for $30 \mathrm{~min}$ at room temperature (RT), followed by a 3 -min incubation at $100{ }^{\circ} \mathrm{C}$. The lysate was then subjected to PCR using the following primers: 
common primer GTTGACCAGAGTGGCGTAGG; WT allele-specific primer GAGCTGATCAGAACCATCATG; Bax-/- allele-specific primer CCGCTTCCATTGCTCAGCGG. The PCR conditions were as follows: 35 cycles of $94{ }^{\circ} \mathrm{C}$ for $45 \mathrm{~s}, 59^{\circ} \mathrm{C}$ for $1 \mathrm{~min} 30 \mathrm{~s}$, and $72{ }^{\circ} \mathrm{C}$ for $2 \mathrm{~min}$. PCR products were sized and identified by gel electrophoresis. Only homozygous WT and Bax $-1-$ mice were used in each experiment.

\section{Identification of PGCs}

Whole embryos were collected at E8.5 and were genotyped using yolk sac tissue. Embryos were fixed in $4 \%$ paraformaldehyde for $2 \mathrm{~h}$ at RT, after which they were rinsed thrice in PBS and incubated in $70 \%$ ethanol for at least $1 \mathrm{~h}$ at RT. After rinsing in PBS, alkaline phosphatase activity within embryos was detected by exposing them to a staining solution containing $0.5 \mathrm{mg} / \mathrm{ml}$ Fast Red TR (Sigma), $10 \mu \mathrm{g} / \mathrm{ml} \alpha$-napthyl phosphate (Sigma), $10 \% \mathrm{MgCl}_{2}$, and $4.5 \%$ borax in water, for 7-10 min. Staining was stopped by rinsing embryos in PBS, and they were then stored in $70 \%$ glycerol in PBS. Embryos were mounted on glass slides and PGCs (identified by dark red staining) were counted, and compared between WT and Bax-1- embryos.

\section{Follicle counts}

To assess naked oocyte and follicle numbers at E13.5, E15.5, PN4, and PN7, ovaries were collected and fixed in Kahle's solution (4\% formalin, $28 \%$ ethanol, and $0.34 \mathrm{M}$ glacial acetic acid) for at least $24 \mathrm{~h}$. Females were distinguished from males based on the absence of the testes-specific coelomic vessel, which forms by E12.5 (Brennan et al. 2002). Following fixation, ovaries were dehydrated and embedded in Paraplast (VWR International, West Chester, PA, USA). Ovaries were serially sectioned at $8 \mu \mathrm{m}$ intervals, mounted on glass slides, stained with Weigert's hematoxylin-picric acid methyl blue, and mounted with Permaslip (Alban Scientific Inc, St Louis, MO, USA). In every fifth section in embryonic ovaries or tenth section in neonatal ovaries, the numbers of naked oocytes, primordial, primary, and preantral follicles were counted. Only follicles containing a visible nucleus were counted to avoid double counting and all counting was done without the knowledge of genotype. Oocytes were counted as naked if they were present in clusters of at least two oocytes with an absence of intervening somatic cells. Follicles were counted as primordial if they contained an oocyte surrounded by flattened granulosa cells, or a mixture of less than seven flattened and cuboidal granulosa cells. Follicles were counted as primary if they contained an oocyte surrounded by a single layer of seven or more cuboidal granulosa cells. Preantral follicles were those containing an oocyte surrounded by two to four complete layers of granulosa cells. Follicle counts are reported as the raw number counted per ovary without a correction factor applied.

\section{Whole-mount immunohistochemistry (wmIHC)}

Ovaries were collected on the morning of E12.5, PN4, and PN7 and washed twice briefly in PT $(0.1 \%$ Triton $X-100$ in PBS) and once for at least $30 \mathrm{~min}$. Ovaries were then incubated in PT $+5 \%$ BSA or heat-inactivated horse serum (hiHS), for 30-60 min, before being incubated with primary antibody diluted in PT with or without $5 \%$ BSA overnight at $4{ }^{\circ} \mathrm{C}$ (anti-phosphohistone H3 (Ser28); 1:100; Upstate Cell Signaling Solutions, Charlottesville, VA, USA) to identify mitotic cells (Gurley et al. 1975, Atchison et al. 2003), and antimouse CD31 platelet endothelial cell adhesion molecule (PECAM-1; 1:50; BD Biosciences Pharmingen, San Jose, CA, USA), and anti-STAT3 (C20; 1:500; Santa Cruz Biotechnology Inc., Santa Cruz, CA, USA) to identify germ cells). Ovaries were then washed in $\mathrm{PT}+1 \% \mathrm{BSA}$, or hiHS, for $30 \mathrm{~min}$, and treated with RNase A for $30 \mathrm{~min}$. DNA was labeled with propidium iodide or TOTO-3 (Invitrogen Molecular Probes) for $20 \mathrm{~min}$, and the ovaries were washed in PT $+1 \%$ BSA, or hiHS, for $30 \mathrm{~min}$. Fluorescein isothiocyanate (FITC) conjugated secondary antibody (Invitrogen Molecular Probes) was diluted in the ratio of $1: 250$ in PT $+5 \%$ $\mathrm{BSA}$, or hiHS, and incubated with the ovaries for $2 \mathrm{~h}$ at RT. Ovaries were then washed thrice in PT $+1 \%$ BSA, or hiHS, for $30 \mathrm{~min}$, then briefly with PBS before being mounted in either Vectashield (Vector Laboratories, Burlingame CA) or Prolong Antifade Kit (Invitrogen Molecular Probes) with Secure-seal imaging spacers (Sigma). Confocal analysis was performed by a Zeiss LSM410 laser-scanning microscope. Images were taken near the surface of the ovary, and then $20 \mu \mathrm{m}$ into the ovary at $63 \times$. At least four images were recorded for each ovary. A phosphohistone H3-labeling index was determined by dividing the number of labeled germ cells by the total number of germ cells. GCN breakdown was assessed at PN4 and PN7 as described in Pepling \& Spradling (2001). Briefly, the number of single oocytes (i.e., those separated from the GCN and incorporated into follicles) relative to the number of oocytes in nests was determined using confocal stacks from 12 to 20 different ovaries. Anti-STAT3 was used as a marker for germ cells in these assays, because it specifically labels the cytoplasm of germ cells and appears continuous when cells are present as nests (Murphy et al. 2005).

\section{Assessment of BrdU incorporation}

To assess 5-bromo-2-deoxyuridine (BrdU) incorporation, we used the technique of Schmahl et al. (2000) with minor modifications. Pregnant mice received a single 
i.p. injection of $\mathrm{BrdU}(50 \mathrm{mg} / \mathrm{kg}$ body weight) on the morning of E12.5, and embryos were collected $2 \mathrm{~h}$ later. Ovaries were isolated from embryos and fixed in 5.3\% formaldehyde in PBS overnight at $4{ }^{\circ} \mathrm{C}$, after which they were washed thrice in PBS. Ovaries were rinsed in $0.6 \%$ Triton X-100 in PBS and then in reaction buffer $(0.1 \mathrm{M}$ Tris (pH 7.5), $50 \mathrm{mM} \mathrm{NaCl}$, and $10 \mathrm{mM} \mathrm{MgCl}_{2}$ ) thrice for $3 \mathrm{~min}$, and then incubated for $1 \mathrm{~h}$ at $37^{\circ} \mathrm{C}$ in $50 \mathrm{U} / \mathrm{ml}$ DNase I (Roche Diagnostic Corporation). Ovaries were then rinsed in $0.6 \%$ Triton X-100 in PBS and incubated with $5 \%$ BSA in PT for $1 \mathrm{~h}$ at RT. Ovaries were incubated with primary antibodies overnight at $4{ }^{\circ} \mathrm{C}$ (anti-BrdU (1:20; BD Biosciences), anti-VASA (1:500), a germ cell marker that was a gift from Toshiaki Noce). The second day followed as described earlier in the wmIHC section.

\section{$3^{\prime}$-End labeling}

$3^{\prime}$-End labeling analysis of apoptosis within ovaries at E15.5 was performed by combining at least 20 ovaries (ten embryos) from each genotype. Ovaries were collected and frozen at $-70{ }^{\circ} \mathrm{C}$ until use. Ovarian DNA was isolated using the DNeasy kit (Qiagen). In each reaction, $0.1-1 \mu \mathrm{g}$ DNA was labeled with $\left[\alpha^{32} \mathrm{P}\right] \mathrm{ddATP}$ (GE Healthcare, formerly Amersham) using the Terminal Transferase reaction kit (Roche Diagnostic Corporation). Labeled DNA was precipitated and separated on a $2 \%$ agarose gel. Individual lanes were excised from the gel after drying and were subjected to scintillation counting. At least three separate labeling experiments were performed for each genotype from the same grouped DNA.

\section{Transferase dUTP nick end labeling (TUNEL) assay}

Ovaries were collected and fixed in Kahle's solution, dehydrated, embedded in Paraplast, serially sectioned at $8 \mu \mathrm{m}$ intervals, and mounted on glass slides. Sections were subjected to terminal deoxynucleotidyl transferase dUTP nick end labeling (TUNEL) analysis using the ApopTag peroxidase in situ apoptosis detection kit (Chemicon International, Temecula, CA, USA), according to the manufacturer's instructions. Sections were counterstained with crystal violet-free methyl green (FD Neuro Technologies, Inc., Baltimore, MD, USA), and then mounted in Permaslip. Apoptotic cells were classified as those staining dark brown by the assay. For comparison of numbers of apoptotic oocytes between genotypes in neonatal ovaries, eight serial sections per ovary were subjected to TUNEL, and the number of labeled oocytes was counted in every second section. Only one ovary per animal was subjected to TUNEL analysis, with at least three ovaries per genotype. The number of apoptotic oocytes was determined without knowledge of genotype.

\section{Immunohistochemistry}

Embryonic ovaries were collected and fixed in $4 \%$ paraformaldehyde for $2 \mathrm{~h}$ at RT, after which they were rinsed in PBS, dehydrated, embedded in Paraplast, serially sectioned at $8 \mu \mathrm{m}$ intervals, and mounted on glass slides. Sections were deparaffinized and rehydrated to water. Antigen retrieval was performed in boiling citrate buffer $(10 \mathrm{mM})$ for $5 \mathrm{~min}$. Slides were washed thrice in $\mathrm{PBS}$, incubated in a $3 \% \mathrm{H}_{2} \mathrm{O}_{2}$ solution in PBS for $10 \mathrm{~min}$ and washed thrice in PBS. Sections were blocked with $5 \%$ hiHS for $1 \mathrm{~h}$, after which endogenous biotin sites were blocked using an avidin-biotin blocking kit (Vector Laboratories, Burlingame, CA, USA) according to the manufacturer's protocol. Slides were washed thrice in PBS and then incubated with primary antibody diluted in the ratio of $1: 100$ in PBS for $48 \mathrm{~h}$ at $4{ }^{\circ} \mathrm{C}$. AntiSCP3 (synaptonemal complex protein 3) and anti-DMC1 were generous gifts of $\mathrm{Dr}$ Chris Ottolenghi at the National Institute on Aging. After incubation with primary antibodies, slides were washed thrice in PBS, and then incubated with appropriate biotin-conjugated secondary antibodies diluted in the ratio of 1:250 in PBS for $1 \mathrm{~h}$ at RT. Slides were washed thrice in PBS, and then incubated with the Vectastain Elite $\mathrm{ABC}$ reagent (Vector Laboratories) for $1 \mathrm{~h}$ at RT. Slides were washed thrice in Tris buffer $(\mathrm{pH} 7.2)$, and then incubated in a $3,3^{\prime}$ diaminobenzidine tetrahydrochloride (DAB; Sigma) solution in Tris buffer for 5-10 min at RT. Slides were then washed thrice in Tris buffer, thrice in PBS, counterstained with picric acid-methyl blue, and dehydrated and mounted in Permaslip.

\section{Statistical analysis}

PGC, oocyte, and follicle numbers between WT and Bax-/- ovaries were compared using Student's $t$-test. GCN breakdown and proliferation data were compared using the Mann-Whitney test. Data for Bax-/ - ovaries from 3 '-end labeling were normalized to WT values and the data were compared using a one-way $t$-test. $P$ values $<0.05$ were considered to be statistically significant.

\section{Results}

\section{Effect of Bax deletion on follicular endowment}

Morphological assessment of oocyte and follicle numbers demonstrated that deletion of Bax increases follicular endowment in mouse ovaries. At all time points between E15.5 and PN7, there were significantly more oocytes and follicles in Bax-/- when compared with WT ovaries (Fig. 1). At E15.5, 4675.2 \pm 216.6 oocytes were counted in Bax $-/-$ ovaries compared with $3650.8 \pm 385.7$ oocytes in WT ovaries ( $n=4$ WT ovaries, $n=5$ Bax $-/-$ ovaries; $P<0.05$; Fig. $1 \mathrm{~A}$ ).

Figure 1B shows the results of follicle counts in PN4 ovaries. There were significantly more naked oocytes 

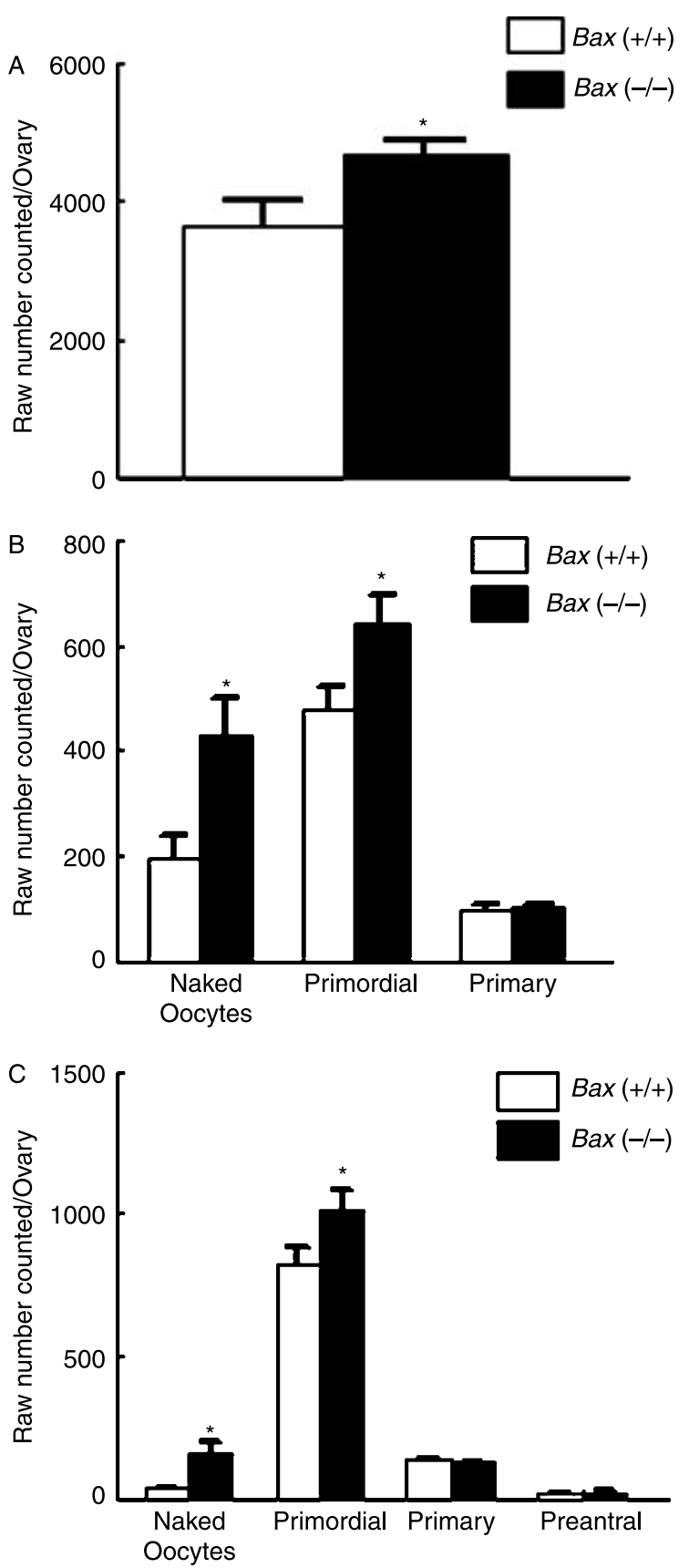

Figure 1 Effect of Bax deletion on follicular endowment as assessed by oocyte and follicle counts in WT and Bax $-/-$ ovaries. (A) E15.5 ( $n=4$ WT ovaries, $n=5$ Bax $-/-$ ovaries; $\left.{ }^{*} P<0.05\right)$. (B) PN4 ( $n=7$ WT ovaries, $n=7$ Bax $-/-$ ovaries; $\left.{ }^{*} P<0.05\right)$. (C) PN7 ( $n=6$ WT ovaries, $n=8$ Bax $-/-$ ovaries; $* P<0.05)$. Bars represent the mean \pm S.E.M. of the raw number counted per ovary.

counted in Bax-/- ovaries $(431.1 \pm 69.5)$ when compared with WT ovaries $(192.6 \pm 43.63 ; n=7$ WT ovaries, $n=7$ Bax $-/-$ ovaries; $P<0.05)$. Similarly, there were significantly more primordial follicles counted in Bax $-/$ - ovaries $(642.1 \pm 56.53)$ when compared with WT ovaries $(477.6 \pm 43.04 ; P<0.05)$. No differences were seen in primary follicle numbers $(P=0.73)$.
Figure 1C shows naked oocyte and follicle numbers in ovaries from PN7 mice. Again, the number of naked oocytes counted in Bax-/- ovaries was significantly greater compared with WT ovaries. There were $161.3 \pm 37.7$ naked oocytes counted in Bax - / - ovaries compared with $35.0 \pm 4.0$ in WT ovaries $(n=6$ WT ovaries, $n=8$ Bax $-/-$ ovaries; $P<0.05)$. Similarly, there were significantly more primordial follicles counted in Bax-/- ovaries $(1019.4 \pm 61.1)$ at PN7 when compared with WT ovaries $(827.2 \pm 60.0 ; P<0.05)$. No differences were seen in the number of primary or preantral follicle numbers between WT and Bax-/ovaries $(P=0.39)$.

\section{Effect of Bax deletion on GCN breakdown}

Figure $2 \mathrm{~A}$ and $\mathrm{B}$ shows the dramatic differences in the morphology of Bax $-/-$ and WT ovaries at PN4, in terms of naked oocytes within GCN. In the WT ovary (Fig. 2A), GCNs persisted but appeared small. In contrast, the Bax-/- ovary (Fig. 2B) contained large GCNs throughout its cortex. Based on these morphological differences, together with the fact that we observed significantly more naked oocytes in Bax-/- when compared with WT ovaries at both PN4 and PN7, we investigated whether Bax deletion impacted GCN breakdown. Using confocal analysis, we observed that GCN breakdown appeared to be delayed in the absence of $B a x$, such that $38.9 \pm 3.1 \%$ of oocytes in WT ovaries at PN4 had been incorporated into follicles, while only $16.9 \pm 2.5 \%$ had been incorporated into follicles in Bax- - ovaries ( $n=12$ WT ovaries, $n=$ 20 Bax $-/-$ ovaries; $P<0.001$; Fig. 2C). Similarly, at PN7, a larger, but not statistically significant, percentage of oocytes in WT ovaries $(55.9 \pm 5.0 \%)$ had been incorporated into follicles when compared with Bax $-/-$ ovaries $(45.6 \pm 2.4 \% ; n=18$ WT ovaries, $n=$ 20 Bax $-/-$ ovaries; $P=0.14$; Fig. 2C). Representative confocal images of WT and Bax-/- ovaries at PN4 are shown in Fig. 2D and $\mathrm{E}$ respectively.

\section{Effect of Bax deletion on oocyte death}

As GCN breakdown is thought to occur by oocyte death (Pepling \& Spradling 2001), we hypothesized that Bax deletion reduces oocyte death in neonatal ovaries resulting in delayed GCN breakdown. To test this hypothesis, we performed TUNEL assays on neonatal Bax-/ - and WT ovaries (Fig. 3). In contrast to our hypothesis, more apoptotic oocytes were observed in Bax-/- ovaries compared with WT ovaries at both PN1 and PN4. At PN1, Bax-/ - ovaries contained 32.9 \pm 7.5 TUNEL-positive oocytes per section compared 14.1 \pm 3.1 TUNEL-positive oocytes per section in WT ovaries $(n=6$ WT ovaries, $n=4$ Bax $-/-$ ovaries; $P<0.05$; Fig. 3A). Similarly, at PN4, Bax-/ - ovaries contained 21.13 \pm 3.17 TUNEL-positive oocytes per section when compared with $7.5 \pm 1.76$ per 

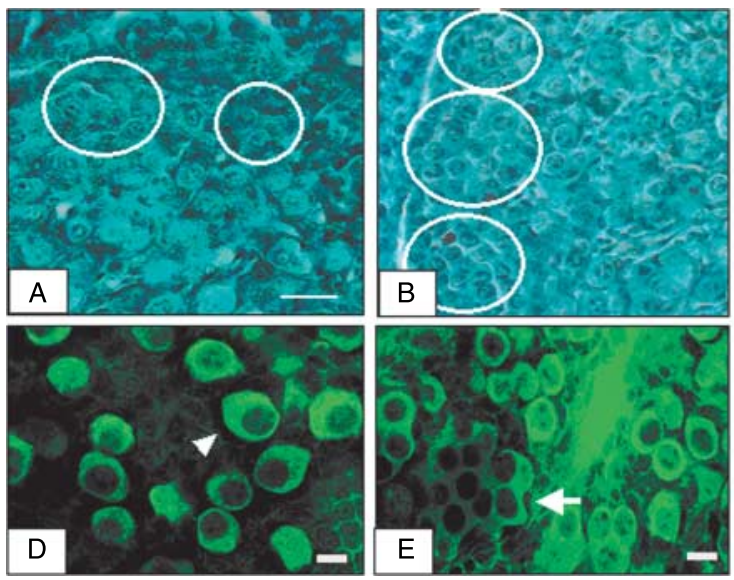

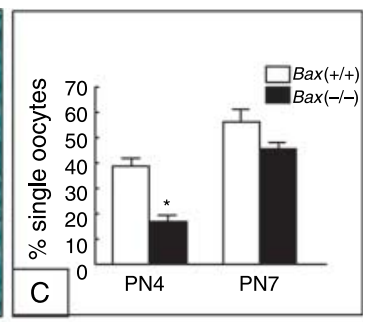

Figure 2 Germ cell nest breakdown. Representative photomicrographs at PN4 for (A) WT and (B) Bax-/- ovaries. GCN are encircled in white. Magnification, $40 \times$. Scale bar, $50 \mu \mathrm{m}$. (C) The percentage of single oocytes in WT and Bax-1ovaries at PN4 $(n=12$ WT ovaries, $n=20$ Bax $-/$ - ovaries; $* P<0.001)$ and PN7 $(n=18 \mathrm{WT}$ ovaries, $n=20$ Bax $-/$ - ovaries; $P=0.14$ ). Bars represent mean \pm s.E.M. Representative confocal image of a (D) WT and (E) Bax-/ - ovary at PN4 labeled with anti-Stat 3 used to calculate the percentage of single oocytes shown in C. The arrow points to an intact germ cell nest. The arrowhead points to a single oocyte. Magnification, $63 \times$. Scale bar, $20 \mu \mathrm{m}$. section in WT ovaries ( $n=3$ WT ovaries, $n=4$ Bax $-/-$ ovaries; $P<0.05$; Fig. 3B). Representative TUNEL sections are shown in Fig. 3C and D.

These findings suggest that differences in GCN breakdown and follicle numbers in neonatal Bax-/- when compared with WT ovaries are not due to enhanced oocyte survival during follicle formation. Therefore, we next tested the hypothesis that increased follicle numbers in Bax $-/-$ mice are due to enhanced oocyte survival during germ cell attrition, by performing 3 '-end labeling reactions at E15.5. As shown in Fig. 4A, more apoptosis was observed in Bax-/- ovaries when compared with WT ovaries. Scintillation counts of radio-labeled DNA revealed that $\mathrm{Bax}-/-$ ovaries contained $232.4 \pm 9.6 \%$, the labeling seen in WT ovaries $(P<0.001$; Fig. 4B). At E18.5, there was no difference in the amount of labeling (Bax-/ $-134.02+28.4 \%$ of WT; $P=0.35$; Fig. 4C). TUNEL analysis showed that the primary cell type undergoing apoptosis at E15.5 is oocytes (Fig. 4D), suggesting that like in neonatal ovaries Bax deficiency does not enhance oocyte survival.

\section{Effect of Bax deletion on PGC allocation}

As enhanced follicular endowment due to Bax deletion is not due to decreased oocyte death, we tested several further hypotheses to explain it. First, we tested whether Bax deletion increases the size of the initial founding population of PGCs. Figure $5 \mathrm{~A}$ and $\mathrm{B}$ shows representative photos of PGCs in WT and Bax-/embryos respectively. As shown in Fig. 5C, Bax deletion did not increase the size of the initial PGC allocation $(\mathrm{WT}=65.3+3.6, \quad$ Bax $-/-=56.3 \pm 4.2$ PGCs; $n=11$ WT embryos, $n=12$ Bax-/- embryos; $P=0.13)$.

\section{Effect of Bax deletion on the onset of meiosis}

We next tested the hypothesis that Bax deletion delays the onset of meiosis by examining the expression of two markers of meiosis. We first performed PCR analysis of Scp3 gene expression at E13.5-15.5. As shown in Fig. 6A, the Scp3 gene was appropriately expressed in Bax-/- when compared with WT ovaries. Next, we examined whether SCP3 and DMC1 protein were appropriately expressed in Bax-/- when compared with WT ovaries. As shown in Fig. 6C-F, SCP3 and DMC1 are appropriately expressed in $\mathrm{Bax}-/-$ when compared with WT ovaries.

\section{Effect of Bax deletion on oogonia proliferation}

Finally, we tested the hypothesis that Bax deletion increases germ cell proliferation. For this hypothesis to have validity, there would have to be differences in germ

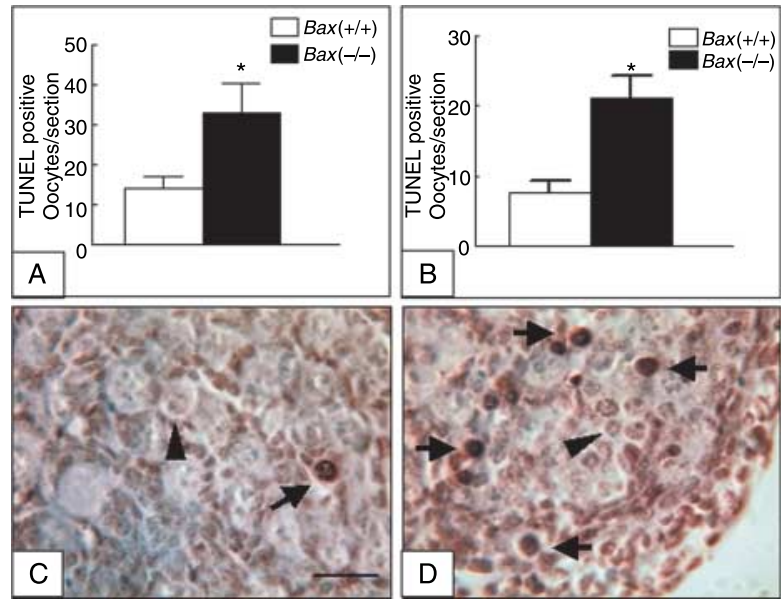

Figure 3 Effect of Bax deletion on oocyte death in neonatal ovaries as assessed by TUNEL analysis. (A) Number of TUNEL-positive oocytes per section in ovaries at PN1 $(n=6$ WT ovaries, $n=4$ Bax-/- ovaries; $\left.{ }^{*} P<0.05\right)$. (B) Number of TUNEL-positive oocytes per section in ovaries at PN4 ( $n=3$ WT ovaries, $n=4$ Bax $-/-$ ovaries; $\left.{ }^{*} P<0.05\right)$. Bars represent mean \pm s.E.M. Representative photomicrographs of PN1 ovaries subjected to TUNEL analysis from (C) WT pups and (D) Bax-/- pups. Arrows point to TUNEL-positive oocytes, arrowheads point to healthy oocytes. Magnification, $63 \times$. Scale bar, $30 \mu \mathrm{m}$. 


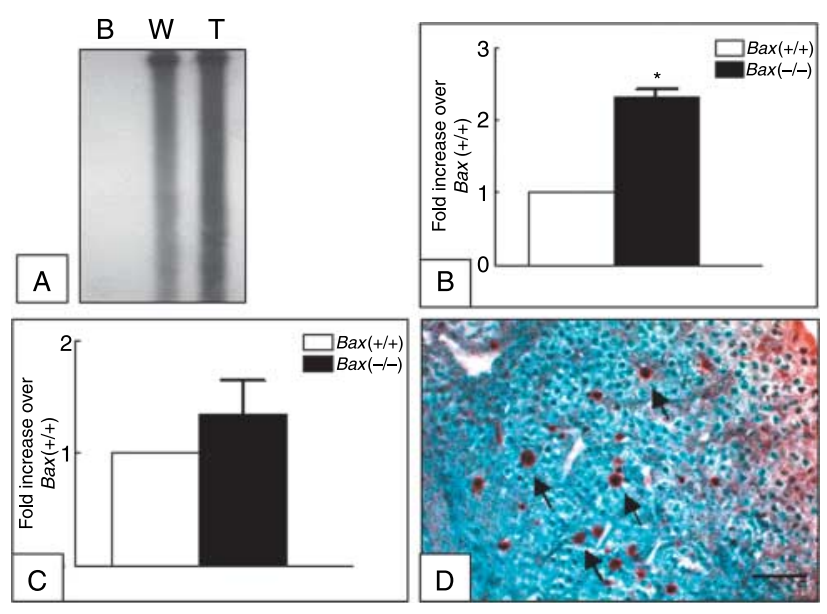

Figure 4 Effect of Bax deletion on germ cell attrition as assessed by 3 '-end labeling reactions of DNA isolated from WT and Bax-/ovaries. (A) Representative gel from a reaction using DNA isolated from ovaries at E15.5 (B, blank; W, WT; and T, Bax-/-). Fold increase of Bax-/- labeling over WT at (B) E15.5 and (C) E18.5 (DNA from at least 20 grouped ovaries per genotype were used in each reaction). Bars represent mean \pm s.E.M. ${ }^{*} P<0.001$. (D) TUNEL assay of ovaries from E15.5 demonstrated that oocytes were the primary cell type undergoing apoptosis. Arrows point to TUNEL positive oocytes. Magnification, $40 \times$. Scale bar, $50 \mu \mathrm{m}$.

cell number between Bax-/- and WT ovaries at the completion of the proliferative period. This is so, as at E13.5, there were significantly more germ cells in Bax-/- (1413.8 \pm 61.6$)$ when compared with WT $(1122.8 \pm 117.9)$ ovaries $(n=4$ WT ovaries, $n=8$ Bax - /- ovaries; $P<0.05$; Fig. 7).

Next, to test whether oogonia were more proliferative in Bax-/- when compared with WT ovaries, we compared the percentage of oogonia that had
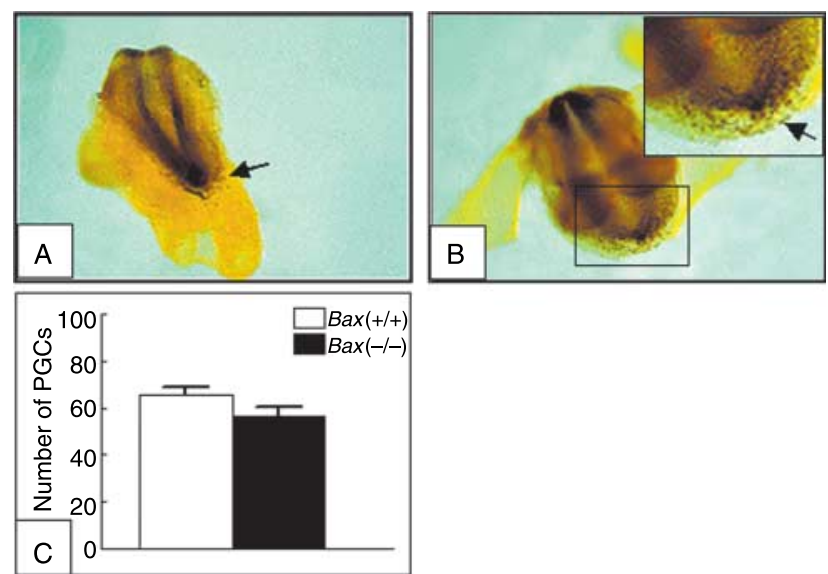

Figure 5 Effect of Bax deletion on germ cell allocation as assessed by primordial germ cell numbers at E8.5. Representative embryos for (A) WT and (B) Bax $-/-$. Region of the embryo containing PGCs is highlighted by the arrow. The inset in $B$ is an enlargement of the area within the square with PGCs being the small red-staining cells highlighted by the arrow. (C) Mean number of PGCs per embryo ( $n=11$ WTembryos, $n=12$ Bax $-/-$ embryos; $P=0.13$ ). Bars represent the mean \pm S.E.M. incorporated BrdU, as well as the percentage of oogonia that labeled with phosphohistone $\mathrm{H} 3$ at E12.5. As shown in Fig. 8A, there was no difference in $\mathrm{BrdU}$ incorporation between $B a x-/-$ ovaries $(50.58 \pm 3.1 \%)$ when compared with WT ovaries $(50.73 \pm 3.2 \% ; n=11$ WT ovaries, $n=6$ Bax-/ovaries; $P=0.96$ ). Similarly, as shown in Fig. $8 \mathrm{~B}$, there was no difference in the percentage of oogonia that labeled with phosphohistone $\mathrm{H} 3$ (WT $=1.03 \pm$ $0.26 \%, B a x-/-=1.49 \pm 0.32 \% ; n=10$ WT ovaries, $n=12$ Bax $-/-$ ovaries; $P=0.28$ ). Representative confocal images are shown in Fig. 8C-E.

\section{Discussion}

Perez et al. (1999) reported that Bax deletion does not affect follicular endowment. We sought to revisit the question of Bax's involvement in follicular endowment in part, because Perez et al. (1999) made their assessment of the effect of Bax deletion on follicle numbers at PN4, too early a time point as follicle formation is not completed before PN7 (Pepling \& Spradling 2001). Additionally, work subsequent to Perez et al. (1999) is highly suggestive of a role for Bax in regulating follicular endowment. Specifically, studies have shown that it is upregulated during germ cell attrition, promotes the death of ectopic PGCs, and corrects the BCL-XL loss of function phenotype, equilibrating oocyte death to WT levels (De Felici et al. 1999, Rucker et al. 2000, Stallock et al. 2003). Thus, we undertook these studies due to the equivocal role for BAX in regulating follicular endowment. In this report, we go beyond these earlier studies and clearly demonstrate that BAX is involved in follicular endowment. This was demonstrated by the fact that there is a surfeit of oocytes and follicles in Bax-/- ovaries when compared with WT ovaries at various times before and near the completion of primordial follicle formation.

Our findings contradict those of Perez et al. (1999) with regard to the effect of Bax deletion on follicle numbers at PN4, in which we observed an increased number of primordial follicles in Bax-/- ovaries when compared with WT ovaries at this time point, whereas they did not observe any difference in follicle numbers between Bax-/- and WT mice at this time point. The reason for this discrepancy is not clear. One possibility is the way in which primordial follicles were classified. We classified a follicle as primordial even if it had a mixture of squamous and cuboidal granulosa cells, despite the fact these follicles have traditionally been regarded as transitioning into primary follicles. We classified these follicles as primordial based on a study by Meredith et al. (2000) in which they demonstrated that these 'transitional' follicles are actually primordial follicles. Discrepancy between our study and Perez et al. (1999) 

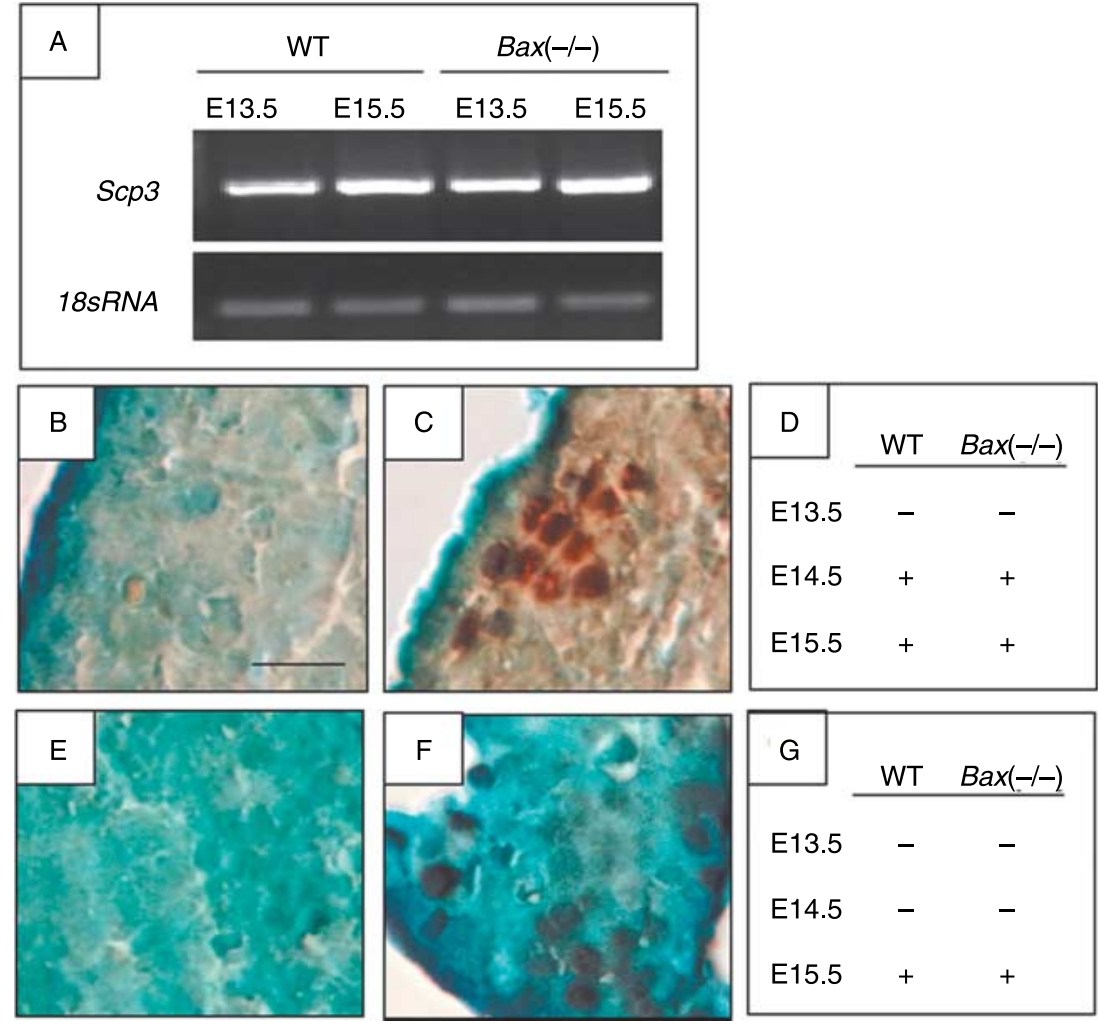

Figure 6 Effect of Bax deletion on the onset of meiosis as assessed by the timing of expression of meiotic markers in embryonic WT and Bax-/ovaries. (A) PCR analysis of $S c p 3$ gene expression in ovaries at E13.5 and E15.5. (B-D) IHC analysis of SCP3 protein expression in embryonic ovaries. (B) Control IHC. (C) Representative image of SCP3-positive oocytes. (D) Table depicting the onset of SCP3 expression in embryonic ovaries. (E-G) IHC analysis of DMC1 expression in embryonic ovaries. (E) Control IHC. (F) Representative image of DMC1-positive oocytes. (G) Table depicting the onset of DMC1 expression in embryonic ovaries. Magnification, $63 \times$. Scale bar, $30 \mu \mathrm{m}$. could potentially be due then to differential classification of these follicles.

Though we saw increased primordial follicle numbers in Bax-/- ovaries, we also saw many more naked oocytes remaining within GCNs. GCN breakdown is thought to be due to apoptosis of oocytes within the nest (Pepling \& Spradling 2001). Since we observed significantly more naked oocytes remaining within GCNs in Bax-1- when compared with WT ovaries, and BAX is a proapoptotic protein, we hypothesized that Bax deletion decreased oocyte death, and delayed the onset or slowed the process of GCN breakdown. In contrast to our hypothesis, we actually observed more oocytes dying in Bax-/- ovaries than in WT ovaries. There was no delay in the onset of GCN breakdown in Bax-/ - ovaries as evidenced by the fact that more oocytes were dying at PN1 when compared with WTs. While it is possible that since only four sections per ovary were subjected to TUNEL analysis that the difference in numbers of dying oocytes could be due to regional differences in oocyte death within the ovary, we tried to use sections collected at similar depths into the ovary, and oocyte death within each ovary appeared to be fairly uniform. Therefore, the difference likely represents a real difference between the genotypes rather than differences based on region within the ovary. The fact that more oocytes were dying in the mutant ovaries is difficult to reconcile with the fact that there was a significantly smaller percentage of single oocytes present in them when compared with WTs (Fig. 2C). It is possible that since there were more oocytes in the Bax-/- ovaries, the increased number of oocytes that were dying represents a similar proportion of apoptotic oocytes when compared with WT. A rough calculation, dividing the mean number of TUNEL-positive oocytes per section at PN4 by the mean number of naked oocytes at PN4, shows that this is the case, with $4.9 \%$ dying in Bax-/- and $3.9 \%$ dying in WTs. The smaller percentage of single oocytes seen in Bax-/- ovaries could be due to the fact that the GCNs in these ovaries

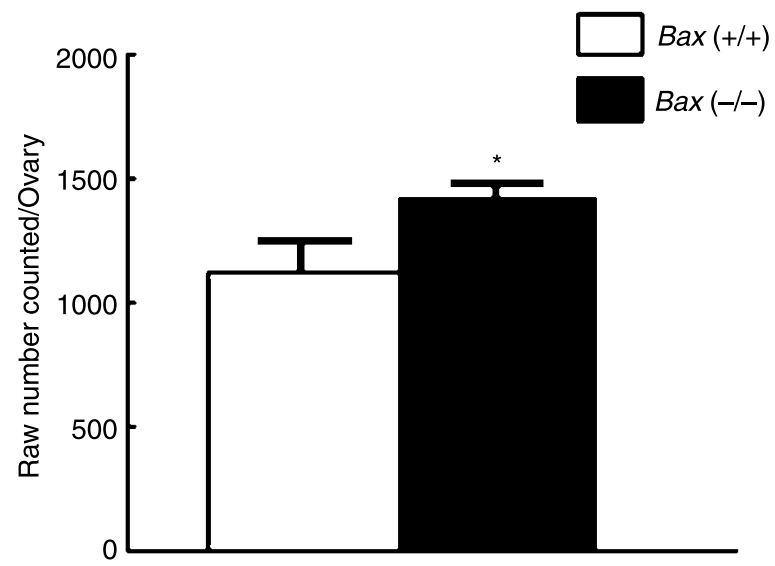

Figure 7 Effect of Bax deletion on germ cell numbers at E13.5 ( $n=4$ WT ovaries, $n=8$ Bax $-/-$ ovaries; ${ }^{*} P<0.05$ ). Bars represent mean \pm S.E.M. of the raw number of germ cells counted per ovary. 

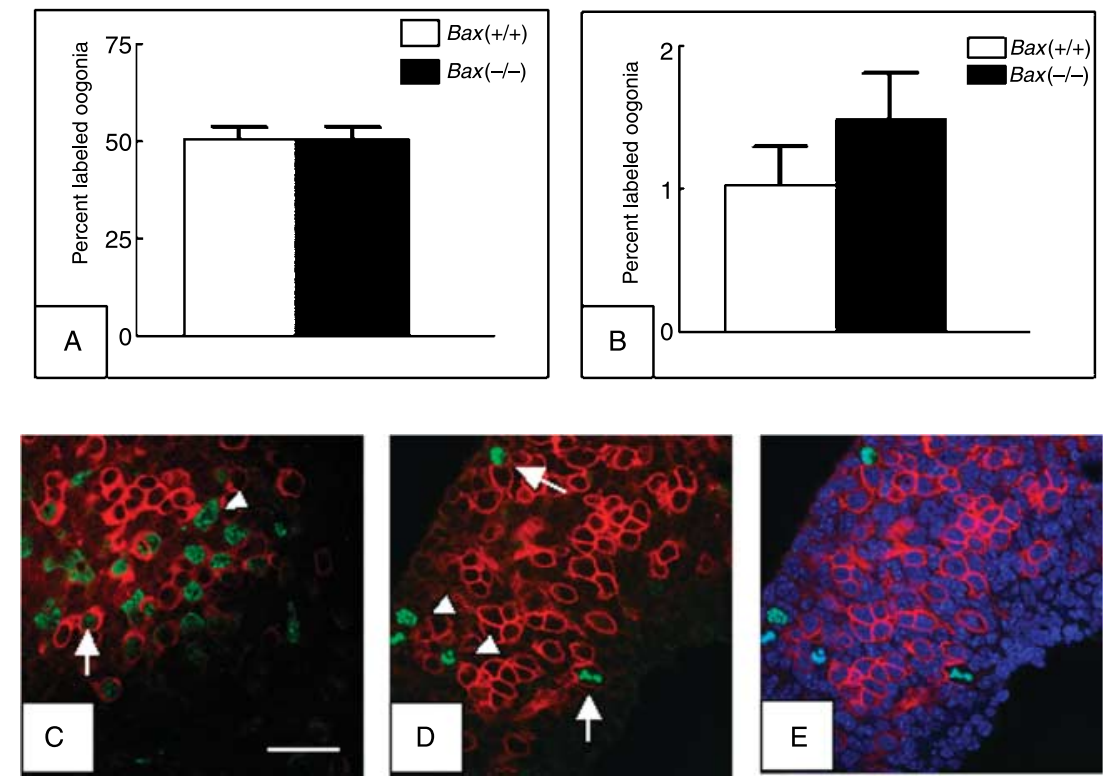

Figure 8 Effect of Bax deletion on cellular proliferation as assessed by wmIHC analysis of $\mathrm{BrdU}$ and phosphohistone $\mathrm{H} 3$ labeling at E12.5. (A) The BrdU labeling index in WT and Bax-/ovaries ( $n=11$ WT ovaries, $n=6$ Bax $-/-$ ovaries; $P=0.96$ ). (B) The phosphohistone $\mathrm{H} 3$-labeling index in WT and Bax-/- ovaries ( $n=10$ WT ovaries, $n=12$ Bax $-/$ - ovaries; $P=0.28$ ). Bars represent mean \pm s.E.M. (C) Representative confocal image a WT ovary labeled with anti-BrdU (green) and anti-VASA (red). (D) Representative confocal image of a WT ovary labeled with anti-phosphohistone $\mathrm{H} 3$ (green) and anti-PECAM (red). (E) The same image as in $D$ but with the nuclear marker TOTO-3 (blue). Arrows point to labeled germ cells, and arrowheads point to labeled somatic cells. Magnification, $63 \times$. Scale bar, $30 \mu \mathrm{m}$. appeared to be much larger than those in their WT counterparts (Fig. 2A and B). Thus, though there are more oocytes undergoing apoptosis within GCNs in Bax-/- ovaries, due to their larger size they may take longer time to fully undergo breakdown.

The fact that we saw a similar proportion of oocytes dying following Bax deletion when compared with WT ovaries suggests that BAX is dispensable for oocyte death in the neonate during GCN breakdown and follicle formation. It is likely that other pro-apoptotic Bcl-2 family members compensate for the absence of BAX to promote oocyte death. Specifically, BAK has been shown in a variety of cell types to have a redundant function with BAX, and in some cell types the deletion of both factors is required to affect the cell's ability to undergo apoptosis (Lindsten et al. 2000, Wei et al. 2001, Zong et al. 2001, Degenhardt et al. 2002). Therefore, it is possible that BAK is able to function in the absence of BAX to promote oocyte death in the neonate and facilitate GCN breakdown and follicle formation.

Since a reduction in the amount of oocyte death occurring in neonatal Bax-/- ovaries could not explain the observed increased follicular endowment, we investigated whether a reduction in oocyte death during germ cell attrition in the embryonic ovary could explain it. This notion is supported by several studies that demonstrate an involvement of BAX in oocyte death at this time. Specifically, De Felici et al. (1999) showed that BAX is upregulated during germ cell attrition and in cultured fetal oocytes undergoing apoptosis. Further, BAX is involved, though not required, for the death of ectopic PGCs that fail to correctly migrate to the ovaries (Stallock et al. 2003). Deletion of Bax also rescues loss of BCL-XL function (Rucker et al. 2000). BCL-XL is an anti-apoptotic
BCL-2 family member, and loss of function was shown to decrease oocyte survival beginning at E13.5. Co-deletion of Bax rescued this phenotype (Rucker et al. 2000). Despite these data supporting a role for BAX in promoting oocyte death during attrition, our data do not support the hypothesis that Bax deletion enhances oocyte survival during germ cell attrition. Similar to what we observed in neonatal ovaries, there was actually more death occurring in Bax $-/$ - ovaries when compared with WTovaries at E15.5. TUNEL analysis demonstrated that increased apoptosis at E15.5, evidenced by increased $3^{\prime}$-end labeling of isolated DNA, was due to oocyte death, rather than somatic cell death, which is consistent with other reports (De Pol et al. 1997, Pepling \& Spradling 2001). It is notable that 3 -end labeling experiments did not yield a typical laddering pattern in the gels characteristic of apoptosis. This is a consistent phenomenon that we observe using embryonic ovaries and similar to what has been observed in other studies (Ratts et al. 1995). One possible explanation for this phenomenon could be that the endonuclease system is not fully matured or functional in the embryonic ovary leading to an absence of clear DNA laddering. This demonstrates that as in oocytes in the neonate, BAX is dispensable for oocyte death in the embryo. For the same reason discussed earlier, it is likely that a redundant factor, for example BAK, acts to promote oocyte death in its absence.

Interestingly, despite the fact that in our study, Bax deletion did not reduce oocyte death within the ovary, Bax deletion was previously observed to delay the death of ectopic germ cells (Stallock et al. 2003). This suggests that germ cell death during attrition is not an autonomous process, and that an atretogenic factor(s) produced within the ovary, and not in ectopic locations, is 
important for promoting oocyte death during attrition, seemingly utilizing a BAX-independent or redundant pathway. This may speak to the mechanism by which germ cell attrition occurs. Bax-/- oocytes are seen to be more viable than WT oocytes following growth factor withdrawal (De Felici et al. 1999, Stallock et al. 2003). If growth factor withdrawal were the mechanism by which germ cell attrition was initiated, then increased death at E15.5 would not be expected. Rather, it would likely be delayed in Bax-1- ovaries as observed in ectopic locations. Therefore, it is more likely that germ cell attrition is an active process.

Our data suggest that the regulatory role of $B a x$ during follicular endowment occurs prior to germ cell attrition. Therefore, we proposed several hypotheses to explain the increased follicle numbers observed following Bax deletion. One hypothesis that we did not test was that Bax deletion enhances the survival of premeiotic oogonia, because oocyte death has largely been observed to begin only after they have entered meiosis (Coucouvanis et al. 1993, Ratts et al. 1995). Enhanced survival of germ cells in a stable population could not explain the increased number of oocytes that we observed in embryonic and PN life. Thus, the first hypothesis we tested was that Bax deletion alters PGC allocation. We did not see an effect of Bax deletion on PGC allocation. Next, we looked at whether Bax deletion delays the onset of meiosis. The rationale behind this hypothesis was that if there were a delay in the onset of meiosis, the proliferative period would be lengthened. Further, Bax deletion has been shown to lead to meiotic defects in males (Knudson et al. 1995). While Bax-/- females are fertile, and oocytes are thus able to normally progress through meiosis, that does not preclude the possibility of a more subtle effect of Bax deletion on meiosis in oocytes, for example, a delayed onset. That said, we did not observe a delay in the onset of meiosis in Bax-/- oocytes when compared with WT oocytes. Based on the expression of the markers SCP3, which is involved in the formation and stability of the synaptonemal complex produced during zygotene and pachytene of prophase I (reviewed in Champion \& Hawley 2002) and DMC1, which is a germ cell-specific protein involved in DNA repair during recombination (Pittman et al. 1998, Yoshida et al. 1998), Bax-/- germ cells entered meiosis at an appropriate time.

Finally, we tested the hypothesis that Bax deletion enhances oogonia proliferation. A large amount of recent data has demonstrated a role for BCL-2 family members in regulating cellular proliferation (reviewed in Bonnefoy-Berard et al. 2004). For example, BCL-2 has been shown to have an inhibitory effect on cell cycle progression in a variety of cell types (Linette et al. 1996, Mazel et al. 1996, O'Reilly et al. 1996, Vairo et al. 1996, Deng et al. 2004). Conversely, Knudson et al. (2001) showed that overexpression of Bax enhances proliferation of thymocytes. However, our data do not support the hypothesis that Bax deletion increases proliferation of oogonia.

The fact that we observed significantly more germ cells present within Bax-/ - when compared with WT ovaries at E13.5, the time at which proliferation ceases and germ cells begin to enter meiosis (McLaren 1988), and a time before the start of germ cell attrition (Coucouvanis et al. 1993, Ratts et al. 1995), is highly suggestive of a role for Bax in the regulation of germ cell function prior to the onset of meiosis. That oogonia proliferation was unaltered by Bax deletion at E12.5, and oogonia death is rare prior to meiosis (Coucouvanis et al. 1993, Ratts et al. 1995), Bax's regulatory role likely takes place prior to germ cell colonization of the gonad. We further showed that Bax deletion does not affect the size of the initial PGC allocation. Therefore, it appears that Bax is an important regulator of PGC function during migration. Stallock et al. (2003) showed that Bax is expressed in migratory PGCs and therefore, it could be that Bax regulates either the survival or proliferation of PGCs during their migration to the developing gonad.

In conclusion, we have shown that BAX is an important negative regulator of follicular endowment in mice, such that in its absence, follicular endowment is increased. Perez et al. (1999) demonstrated that Bax-/- females have prolonged reproductive longevity due to reduced atresia of immature follicles. Our study suggests that another reason for prolonged reproductive lifespan in Bax $-/-$ mice is an increased follicular endowment. The mechanism by which BAX acts to regulate follicular endowment is unclear, but we have shown that it is independent of changes in germ cell viability. This study has implications in terms of the interpretation of previous results regarding the role of apoptotic regulatory genes during follicular endowment. For example, deletion of $\mathrm{BCl}-2$ was shown to decrease the follicular endowment (Ratts et al. 1995), whereas overexpression of $\mathrm{BCl}-2$ was shown to increase it (Flaws et al. 2001). It was logically assumed that these results were due to altered germ cell viability during development. However, in the light of this study, it is possible that BCL-2, like BAX, may regulate follicular endowment independent of regulating germ cell apoptosis. A comparison of these studies could yield potential clues as to how these factors regulate germ cell function, and how germ cell death is regulated during development.

\section{Acknowledgements}

This work was supported by NIH 38 955, T32HD07170. The authors declare that there is no conflict of interest that would prejudice the impartiality of this scientific work. 


\section{References}

Atchison FW, Capel B \& Means AR 2003 Pin1 regulates the timing of mammalian primordial germ cell proliferation. Development 130 3579-3586.

Bergeron L, Perez GI, Macdonald G, Shi L, Sun Y, Jurisicova A, Varmuza S, Latham KE, Flaws JA, Salter JC et al. 1998 Defects in regulation of apoptosis in caspase-2-deficient mice. Genes and Development 12 1304-1314.

Bonnefoy-Berard N, Aouacheria A, Verschelde C, Quemeneur L, Marcais A \& Marvel J 2004 Control of proliferation by Bcl-2 family members. Biochimica et Biophysica Acta 1644 159-168.

Brennan J, Karl J \& Capel B 2002 Divergent vascular mechanisms downstream of Sry establish the arterial system in the XY gonad. Developmental Biology 244 418-428.

Champion MD \& Hawley RS 2002 Playing for half the deck: the molecular biology of meiosis. Nature Cell Biology 4 s50-s56.

Coucouvanis EC, Sherwood SW, Carswell-Crumpton C, Spack EG \& Jones PP 1993 Evidence that the mechanism of prenatal germ cell death in the mouse is apoptosis. Experimental Cell Research 209 238-247.

Degenhardt K, Sundararajan R, Lindsten T, Thompson C \& White E 2002 Bax and Bak independently promote cytochrome c release from mitochondria. Journal of Biological Chemistry 277 14127-14134.

Deng X, Gao F, Flagg T \& May WS Jr 2004 Mono- and multisite phosphorylation enhances BCl-2's antiapoptotic function and inhibition of cell cycle entry functions. PNAS 101 153-158.

De Felici M, Di Carlo A, Pesce M, lona S, Farrace MG \& Piacentini M $1999 \mathrm{Bcl}-2$ and bax regulation of apoptosis in germ cells during prenatal oogenesis in the mouse embryo. Cell Death and Differentiation 6 908-915.

De Felici M, Scaldaferri ML, Lobascio M, Iona S, Nazzicone V, Klinger FG \& Farini D 2004 Experimental approaches to the study of primordial germ cell lineage and proliferation. Human Reproduction Update 10 197-206.

Flaws JA, Hirshfield AN, Hewitt JA, Babus JK \& Furth PA 2001 Effect of $\mathrm{Bcl}-2$ on the primordial follicle endowment in the mouse ovary. Biology of Reproduction 64 1153-1159.

Flaws JA, Marion SL, Miller KP, Christian PJ, Babus JK \& Hoyer PB 2006 Effect of $b c l-2$ overexpression in mice on ovotoxicity caused by 4-vinylcyclohexene. Toxicology and Applied Pharmacology 215 51-56.

Ginsburg M, Snow MH \& McLaren A 1990 Primordial germ cells in the mouse embryo during gastrulation. Development 110 521-528.

Gomperts M, Garcia-Castro M, Wylie C \& Heasman J 1994 Interactions between primordial germ cells play a role in their migration in mouse embryos. Development 120 135-141.

Greenfeld C \& Flaws JA 2004 Renewed debate over postnatal oogenesis in the mammalian ovary. Bioessays 26 829-832.

Gulbins E 2003 Regulation of death receptor signaling and apoptosis by ceramide. Pharmacological Research 47 393-399.

Gurley LR, Walters RA \& Tobey RA 1975 Sequential phosphorylation of histone subfractions in the Chinese hamster cell cycle. Journal of Biological Chemistry 250 3936-3944.

Hirshfield AN 1991 Development of follicles in the mammalian ovary. International Review of Cytology 124 43-101.

Johnson J, Canning J, Kaneko T, Pru JK \& Tilly JL 2004 Germline stem cells and follicular renewal in the postnatal mammalian ovary. Nature 428 145-150.

Johnson J, Bagley J, Skaznik-Wikiel M, Lee HJ, Adams GB, Niikura Y, Tschudy KS, Tilly JC, Cortes ML, Forkert R et al. 2005 Oocyte generation in adult mammalian ovaries by putative germ cells in bone marrow and peripheral blood. Cell 122 303-315.

Knudson CM, Tung KS, Tourtellotte WG, Brown GA \& Korsmeyer SJ 1995 Bax-deficient mice with lymphoid hyperplasia and male germ cell death. Science $\mathbf{2 7 0}$ 96-99.

Knudson CM, Johnson GM, Lin Y \& Korsmeyer SJ 2001 Bax accelerates tumorigenesis in p53-deficient mice. Cancer Research 61 659-665.
Lawson KA \& Hage WJ 1994 Clonal analysis of the origin of primordial germ cells in the mouse. Ciba Foundation symposium 182 68-91.

Lindsten T, Ross AJ, King A, Zong WX, Rathmell JC, Shiels HA, Ulrich E, Waymire KG, Mahar P, Frauwirth K et al. 2000 The combined functions of proapoptotic Bcl-2 family members Bak and Bax are essential for normal development of multiple tissues. Molecular Cell 6 1389-1399.

Linette GP, Li Y, Roth K \& Korsmeyer SJ 1996 Cross talk between cell death and cell cycle progression: $\mathrm{Bcl}-2$ regulates NFAT-mediated activation. PNAS 93 9545-9552.

Mazel S, Burtrum D \& Petrie HT 1996 Regulation of cell division cycle progression by bcl-2 expression: a potential mechanism for inhibition of programmed cell death. Journal of Experimental Medicine 183 2219-2226.

McClellan KA, Gosden R \& Taketo T 2003 Continuous loss of oocytes throughout meiotic prophase in the normal mouse ovary. Developmental Biology 258 334-348.

McLaren A 1988 The developmental history of female germ cells in mammals. Oxford Reviews of Reproductive Biology 10 162-179.

Meredith S, Dudenhoeffer G \& Jackson K 2000 Classification of small type B/C follicles as primordial follicles in mature rats. Journal of Reproduction and Fertility 119 43-48.

Molyneaux K \& Wylie C 2004 Primordial germ cell migration. International Journal of Developmental Biology 48 537-544.

Molyneaux KA, Wang Y, Schaible K \& Wylie C 2004 Transcriptional profiling identifies genes differentially expressed during and after migration in murine primordial germ cells. Gene Expression Patterns 4 167-181.

Morita Y, Perez GI, Paris F, Miranda SR, Ehleiter D, HaimovitzFriedman A, Fuks Z, Xie Z, Reed JC, Schuchman EH et al. 2000 Oocyte apoptosis is suppressed by disruption of the acid sphingomyelinase gene or by sphingosine-1-phosphate therapy. Nature Medicine 6 1109-1114.

Murphy K, Carvajal L, Medico L \& Pepling M 2005 Expression of Stat3 in germ cells of developing and adult mouse ovaries and testes. Gene Expression Patterns 5 475-482.

O'reilly LA, Huang DC \& Strasser A 1996 The cell death inhibitor Bcl-2 and its homologues influence control of cell cycle entry. $E M B O$ Journal 15 6979-6990.

Pepling ME \& Spradling AC 1998 Female mouse germ cells form synchronously dividing cysts. Development 125 3323-3328.

Pepling ME \& Spradling AC 2001 Mouse ovarian germ cell cysts undergo programmed breakdown to form primordial follicles. Developmental Biology 234 339-351.

Perez GI, Robles R, Knudson CM, Flaws JA, Korsmeyer SJ \& Tilly JL 1999 Prolongation of ovarian lifespan into advanced chronological age by Bax-deficiency. Nature Genetics 21 200-203.

Pittman DL, Cobb J, Schimenti KJ, Wilson LA, Cooper DM, Brignull E, Handel MA \& Schimenti JC 1998 Meiotic prophase arrest with failure of chromosome synapsis in mice deficient for Dmc1, a germline-specific RecA homolog. Molecular Cell 1 697-705.

De Pol A, Vaccina F, Forabosco A, Cavazzuti E \& Marzona L 1997 Apoptosis of germ cells during human prenatal oogenesis. Human Reproduction 12 2235-2241.

Ratts VS, Flaws JA, Kolp R, Sorenson CM \& Tilly JL 1995 Ablation of $b c l-2$ gene expression decreases the numbers of oocytes and primordial follicles established in the post-natal female mouse gonad. Endocrinology 136 3665-3668.

Ren S, Li M, Cai H, Hudgins S \& Furth PA 2001 A simplified method to prepare PCR template DNA for screening of transgenic and knockout mice. Contemporary Topics in Laboratory Animal Science 40 27-30.

Reynaud K \& Driancourt MA 2000 Oocyte attrition. Molecular and Cellular Endocrinology 163 101-108.

Rucker EB III, Dierisseau P, Wagner KU, Garrett L, Wynshaw-Boris A, Flaws JA \& Hennighausen L $2000 \mathrm{Bcl}-\mathrm{x}$ and bax regulate mouse primordial germ cell survival and apoptosis during embryogenesis. Molecular Endocrinology 14 1038-1052. 
Schmahl J, Eicher EM, Washburn LL \& Capel B 2000 Sry induces cell proliferation in the mouse gonad. Development 127 65-73.

Stallock J, Molyneaux K, Schaible K, Knudson CM \& Wylie C 2003 The pro-apoptotic gene $B a x$ is required for the death of ectopic primordial germ cells during their migration in the mouse embryo. Development 130 6589-6597.

Starz-Gaiano M \& Lehmann R 2001 Moving towards the next generation. Mechanisms of Development 105 5-18.

Tam PP \& Snow MH 1981 Proliferation and migration of primordial germ cells during compensatory growth in mouse embryos. Journal of Embryology and Experimental Morphology 64 133-147.

Tam PP \& Zhou SX 1996 The allocation of epiblast cells to ectodermal and germ-line lineages is influenced by the position of the cells in the gastrulating mouse embryo. Developmental Biology 178 124-132.

Telfer EE, Gosden RG, Byskov AG, Spears N, Albertini D, Yding Andersen C, Anderson R, Braw-Tal R, Clarke H, Gougeon A et al. 2005 On regenerating the ovary and generating controversy. Cell 122 821-822.

Vairo G, Innes KM \& Adams JM $1996 \mathrm{Bcl}-2$ has a cell cycle inhibitory function separable from its enhancement of cell survival. Oncogene 13 1511-1519.
Wei MC, Zong WX, Chen EH, Lindsten T, Panoutsakopoulou V, Ross AJ, Roth KA, MacGregor GR, Thompson CB \& Korsmeyer SJ 2001 Proapoptotic BAX and BAK: a requisite gateway to mitochondrial dysfunction and death. Science 292 727-730.

Yoshida K, Kondoh G, Matsuda Y, Habu T, Nishimune Y \& Morita T 1998 The mouse RecA-like gene Dmc1 is required for homologous chromosome synapsis during meiosis. Molecular Cell 1 707-718.

Zong WX, Lindsten T, Ross AJ, MacGregor GR \& Thompson CB 2001 $\mathrm{BH} 3$-only proteins that bind pro-survival $\mathrm{BCl}-2$ family members fail to induce apoptosis in the absence of Bax and Bak. Genes and Development 15 1481-1486.

Zuckerman S 1951 The number of oocytes in the mature ovary. Recent Progress in Hormone Research 6 63-108.

Received 13 October 2006

First decision 21 November 2006

Accepted 26 January 2007 